\title{
TEMPERATURE-DEPENDENT DEVELOPMENT OF IMMATURE STAGES OF PREDATORY LADYBIRD BEETLE STETHORUS VAGANS (COLEOPTERA: COCCINELLIDAE) AT CONSTANT AND FLUCTUATING TEMPERATURES
}

\author{
InAmullah KHAN ${ }^{1}$ and Robert SpoOner-HART ${ }^{2}$ \\ ${ }^{1}$ Department of Plant Protection, The University of Agriculture Peshawar \\ KhyberPakhtunkhwa Pakistan, E-mail:dr.inam@aup.edu.pk \\ ${ }^{2}$ University of Western Sydney, Hawkesbury Campus, Penrith, NSW 2751, Australia \\ E-mail: R.Spooner-Hart@westernsydney.edu.au
}

\begin{abstract}
Influence of temperature on the development of the predatory ladybird, Stethorus vagans Blackburn, fed on Tetranychus urticae Koch was assessed at seven constant $(10,12,15,20$, 25,30 and $\left.35^{\circ} \mathrm{C}\right)$ and fluctuating $\left(12.7-32.1^{\circ} \mathrm{C}\right)$ temperatures. There was a strong positive correlation $(\mathrm{r}=0.99)$ between rate of development and temperature. The development times from egg to adult emergence were $65.2 \pm 2.3$ and $9.2 \pm 0.3$ days at 12 and $30^{\circ} \mathrm{C}$ constant, respectively and $15.4 \pm 0.3$ days at fluctuating temperature. Average egg incubation period decreased from $16.5 \pm 0.8$ to $2.18 \pm 0.2$ days with increasing temperatures from 12 to $30{ }^{\circ} \mathrm{C}$, respectively and was $4.1 \pm 0.3$ days at the fluctuating temperature. Eggs did not develop at $10{ }^{\circ} \mathrm{C}$; however, they could survive a long period of exposure to this temperature. None of two hundred eggs that were placed at a constant temperature of $10^{\circ} \mathrm{C}$ for 60 days hatched; but when they were subsequently exposed to $\geq 15^{\circ} \mathrm{C}$, more than 120 of them hatched. Eggs appeared to develop normally at $35^{\circ} \mathrm{C}$, however, larvae died before or immediately after emergence. The lower development threshold temperature for egg, 1st, 2nd, 3rd, 4th larval instars, pupal and all these stages combined was 10.1, 9.5, 9.5, 9.1, 8.2, 8.0, and $9.1^{\circ} \mathrm{C}$, respectively. Degree-day (DD) accumulation was also calculated for each stage as well as for all stages combined. It was estimated to be $189.2 \pm 4.8 \mathrm{DD}$ at $12{ }^{\circ} \mathrm{C}$ and $207.8 \pm 6.9 \mathrm{DD}$ at $30^{\circ} \mathrm{C}$ constant, respectively, and 189.1 $\pm 5.0 \mathrm{DD}$ at fluctuating temperatures.
\end{abstract}

Key words: rate of development, predatory ladybird beetle, Stethorus vagans, Degree Days, two-spotted mite.

\section{INTRODUCTION}

Two-spotted spider mite (TSSM), Tetranychus urticae Koch, is a major pest of more than 200 plants of economic importance worldwide, including a large number of greenhouse crops, a wide range of field crops, vegetables, strawberry, deciduous fruit trees, walnuts, almond, berries hops, cucurbits, cut flowers, ornamental shrubs, vines, and various other plants (Costello et al. 1992, Gough 1992, Hutchison 1992, Bower \& Thwaite 1995, McMaugh, 1998, Han et al. 2003, Jung 2005, KHERAdPIR et al. 2007). A number of acaricides and insecticides have been introduced for the control of T. urticae, but it has 
developed resistance against these chemicals, while some were withdrawal due to health hazards and environmental pollution (Penrose et al. 1997). This suggests that the problem of controlling T. urticae deteriorates if the cost of developing and marketing of new compounds becomes prohibitive (READSHAw 1975). Therefore, interest has increased in biological control of this pest. Many insects as well as several families of mites are recorded as good biological agents of tetranychid pests (Gordon \& Anderson 1979, Houston 1980, Helle \& SABELIS 1985).

All known species of Stethorus have been reported to attack spider mites of economic importance. Both adults and larvae are highly specialized predators of tetranychid mites (Houston 1980, Helle \& Sabelis 1985, Hull 1977, Roy et al. 2005). Biological studies have been conducted on several species of Stethorus. Most of the species complete their life cycle (egg-adult) in two weeks and have five generations a year under optimal temperature conditions, which is slightly longer than that required for the development of most mite species in green houses in England and in field in India (Jeppson et al. 1975, Pavlova 1975, Singh \& Ray 1977). One of the species belong to this genus, Stethorus vagans Koch (Coleoptera: Coccinellidae), native to Australia, has been observed in close association with T. urticae in various agricultural and horticultural crops, and ornamental plants system (READSHAw 1975, GoRdON \& Anderson 1979, Houston 1980, Helle \& Sabelis 1985). This species is capable of detecting and attacking populations of T. urticae at very low density, distributed in small and widely scattered patches (KHAN 2001). However, there are only a few papers published on this species, mainly on its taxonomic description and its presence in the orchards where T. urticae are found (READshaw 1975, Gordon \& Anderson 1979, Houston 1980, Helle \& Sabelis 1985).

The success of biological control is dependent on the synchronization of the pest and predator, which depends on their population growth rate, dispersal ability, voracity and fitness. Synchronization both species is mainly dependent on biotic and abiotic factors, of which the latter play a major role (HufFaker et al. 1999). Among abiotic factors temperature, photoperiod and relative humidity are probably the most important that influence the rate of development and survival of living organisms; however temperature is the most crucial one, as it greatly affects developmental rate of various insect pests and their natural enemies, which in turn influence their seasonal occurrence and population dynamics (Andrewartha \& Birch 1954, HoneK \& Kocourek 1990, Huffaker et al. 1999, Roy et al. 2002). Knowledge of temperature-dependent development is essential for understanding the dynamics of predator-prey relationships, their biology, ecology and distribution, which are also useful in the enhancing of mass rearing (Rodriguez-SaOna \& Miller 1999), and predicting their development and activity in the field (FAN et al. 1992). 
Temperature-dependent models are widely used to predict population density and rate of development of insect pests and their natural enemies (Woodson \& Edelson 1988, Hayakawa et al. 1990, Deloach 1974), for example corn leaf aphid, Rhopalosiphum maidis (ELLiotT et al. 1988), navel orange worm Amyelois transitella (SANDERson et al. 1989), Mexican bean beetle Epilachna varivestis (FAN et al. 1992), and the coccinellids Hippodamia sinuata (Michels \& BEHLE 1991) and Stethorus bifidus (Petersons et al. 1994). No data have been published on the Degree-Day (DD) requirement in the genus Stethorus, except for S. bifidus. A study had already been done on the developmental rate and DD of Tetranychus urticae, while, no similar data were available for its predator Stethorus vagans (Coleoptera: Coccinellidae). Therefore the present study was undertaken to obtain developmental data over a wide range of constant and fluctuating temperatures, which could be used to calculate the lower developmental threshold temperatures and to construct a DD model for S. vagans. It also aimed to assist interpretation and prediction of seasonal development of S. vagans in the field and its synchronization with its host T. urticae.

\section{MATERIAL AND METHODS}

\section{Field collection and stock colony}

Adult predatory ladybird beetle Stethorus vagans were collected from the field on potted French bean plants (Vicia faba cv. Redland Pioneer) infested with Tetranychus urticae. A culture colony from these predators was established at $25 \pm 0.1^{\circ} \mathrm{C}$ with a photoperiod of $16: 8$ (L: D) and RH 60 $\pm 5 \%$ in a temperature-controlled cabinet (Thermoline incubators (internal dimension $122 \times 52.5 \times 43 \mathrm{~cm}$ ). Catalogue number RI 250, Thermoline Scientific Equipment Pty Ltd., 40 Blackstone Street, Wetherill Park, NSW 2164, Australia) in the laboratory. Stock colony of TSSM was maintained on French bean plants in a screen house between $25-27^{\circ} \mathrm{C}$ and $\mathrm{RH} 50-75 \%$ for regularly supply for the $S$. vagans culture and experimental work in the laboratory and field. All collections and experimental work were carried out at the Centre for Horticulture and Plant Sciences, University of Western Sydney, Hawkesbury campus, Richmond (33 $\left.36^{\prime} \mathrm{S}, 150^{\circ} 44^{\prime} \mathrm{E}\right)$, New South Wales, Sydney, Australia.

\section{Experimental conditions}

S. vagans development was studied at nine constant $\left(10-40^{\circ} \mathrm{C}\right)$ as well as at fluctuating temperatures $\left(12.7-32.1^{\circ} \mathrm{C}\right)$. Initially, adult predators were randomly selected from the stock colony and paired over a $2.5 \mathrm{~cm}$ diameter bean leaf discs infested with TSSM. These discs were maintained on water-saturated foam in polystyrene sealable petri dishes (Falcon plastic, Oxnard, CA), which had a 3-cm diameter hole in the upper lid and was covered with nylon cloth. These petri dishes were randomly allocated to nine Thermoline illuminated incubators units set at constant temperatures, 10, 12, 15, 20, 25, 30, 32, 35 and $40{ }^{\circ} \mathrm{C}\left( \pm 0.1^{\circ} \mathrm{C}\right)$ at photoperiod of $16 \mathrm{~L}$ : 8D h and $\mathrm{RH}$ of $44-66 \%$. Separate experiments were 
conducted at higher $\mathrm{RH} 70-85 \%$ for $30,32,35$ and $40{ }^{\circ} \mathrm{C}\left( \pm 0.1^{\circ} \mathrm{C}\right)$; because no egg hatch was initially observed for these temperatures at previous RH $44-66 \%$.

Eggs deposited were carefully isolated by cutting the section of leaf containing the egg and placed it singly on a $4.7-\mathrm{cm}$ diameter dry filter paper in the aforementioned Petri dishes. One individual per Petri dish was considered a replicate and each temperature treatment had 50 replicates, except $10{ }^{\circ} \mathrm{C}$ at which 200 eggs were exposed. After egg hatching, its survival and incubation period was recorded. Larval instars were supplied daily with excess prey of all stages of TSSM by brushing infested bean leaves with a mite brushing machine. During larval development, cast exuviae observed were removed to determine the number of moults and the duration of each stage. Pupal survival and duration were also noted and recorded, accordingly.

A similar experimental setup was followed at fluctuating $\left(12.7-32.1^{\circ} \mathrm{C}\right)$ temperature. Petri-dishes were maintained in the well ventilated laboratory room. A temperature and relative humidity data logger (Tinytag, Hastings Data Loggers, Kempsey, NSW, Australia) was placed among the Petri dishes to log data hourly. Data were recorded as for the constant temperatures.

\section{Statistical analysis}

Mean development time of eggs, larvae and pupae, and all immature stages combined of $S$. vagans were calculated. Development rate for each life stage and all stages combined were derived by taking the reciprocal of mean development time (1/d). The relationships between temperature and developmental time were estimated by least-squares linear regression analysis in SAS (PROC REG, SAS Institute 1989). The lower developmental threshold temperatures for each specific stage as well as for all stages combined were derived from the regression equation at $\mathrm{a}=0.05$.

$$
y=a+b x
$$

where $y$ is the developmental rate (expressed as 1/days) at temperature $x$ and $a$ and $b$ are estimates of the $y$ intercept and slope respectively (SoKAL \& RoHLF 1995). The degree-days (DD) were computed for development of each life stage and total stages using the method outlined by PRICE (1997):

$$
D D=D(T-t)
$$

where $D D$ degree-days needed for development at a specific temperature, $D$ mean numbers of days required for development at a certain temperature, $T$ temperature at which the development was observed, $t$ minimum threshold temperature for development. The mean $D D$ required for development of each life stage was obtained by averaging its $D D$ associated with all temperature regimes separately for eggs, larval instars and pupae. The mean $D D$ for for $S$. vagans was calculated from the data obtained from all stages combined.

\section{RESULTS}

\section{Developmental time}

Developmental time of each life stage and all stages combined (egg-adult emergence) of $S$. vagans decreased as temperature increased. Mean total development times from egg to adult emergence at constant and fluctuating 
Table1. Development time (days, mean \pm SE ) of immature stages of $S$. vagans at constant and fluctuating temperatures.

\begin{tabular}{|c|c|c|c|c|c|c|c|}
\hline \multirow{2}{*}{ Stage } & \multirow[b]{2}{*}{$\mathrm{n}$} & \multicolumn{5}{|c|}{ Constant temperature } & \multirow{2}{*}{$\begin{array}{c}\begin{array}{c}\text { Fluctuating } \\
\text { temperature }\end{array} \\
21.4^{\circ} \mathrm{C} \\
\left(12.7-32.1^{\circ} \mathrm{C}\right)\end{array}$} \\
\hline & & $12{ }^{\circ} \mathrm{C}$ & $15^{\circ} \mathrm{C}$ & $20^{\circ} \mathrm{C}$ & $25^{\circ} \mathrm{C}$ & $30^{\circ} \mathrm{C}$ & \\
\hline Egg & 96 & $16.5 \pm 0.8$ & $9.9 \pm 0.7$ & $5.2 \pm 0.5$ & $3.8 \pm 0.4$ & $2.2 \pm 0.3$ & $4.1 \pm 0.3$ \\
\hline 1st instar larva & 96 & $7.8 \pm 0.6$ & $3.4 \pm 0.7$ & $2.2 \pm 0.6$ & $1.3 \pm 0.4$ & $1.0 \pm 0.3$ & $1.6 \pm 0.3$ \\
\hline 2nd instar larva & 96 & $7.6 \pm 0.7$ & $3.3 \pm 0.5$ & $2.2 \pm 0.6$ & $1.4 \pm 0.4$ & $1.0 \pm 0.3$ & $1.7 \pm 0.4$ \\
\hline 3rd instar larva & 96 & $8.0 \pm 0.9$ & $3.5 \pm 0.6$ & $2.2 \pm 0.6$ & $1.4 \pm 0.4$ & $1.0 \pm 0.3$ & $1.6 \pm 0.3$ \\
\hline 4th instar larva & 96 & $9.1 \pm 0.6$ & $3.6 \pm 0.5$ & $2.2 \pm 0.7$ & $1.6 \pm 0.4$ & $1.2 \pm 0.3$ & $1.7 \pm 0.3$ \\
\hline Pupa & 96 & $16.3 \pm 0.5$ & $9.5 \pm 0.5$ & $4.4 \pm 0.5$ & $3.1 \pm 0.4$ & $2.8 \pm 0.3$ & $4.7 \pm 0.4$ \\
\hline All stages combi & & $65.2 \pm 2.3$ & $33.2 \pm 0.6$ & $18.2 \pm 0.5$ & $13.1 \pm 0.4$ & $9.2 \pm 0.3$ & $15.4 \pm 0.3$ \\
\hline
\end{tabular}

temperatures $\left(12.7-32.1^{\circ} \mathrm{C}\right)$ are presented in Table 1 . The egg developmental period varied from $16.5 \pm 0.8$, at $12^{\circ} \mathrm{C}$ and $2.2 \pm 0.3$ days at $30^{\circ} \mathrm{C}$, although in the latter case eggs only hatched at higher relative humidity (70-85\%). The egg incubation period recorded at fluctuating temperatures was $4.1 \pm 0.3$ days. At $10^{\circ} \mathrm{C}$, eggs survived for a longer period without any embryonic development. Of the initial 200 eggs exposed to $10^{\circ} \mathrm{C}$ for 60 days, none showed sign of development. However, more than 120 of these eggs hatched within the normal time period when they were subsequently exposed to $\geq 15^{\circ} \mathrm{C}$. At $35^{\circ} \mathrm{C}$ eggs appeared to develop normally, but larvae died before or just after hatching. There were four larval instars, which were differentiated from each other by the presence of shed exoskeleton and differences in head capsule size (viz., larvae moulted three times before going to pupation). Mean duration of egg, all four larval instars, pupa and all stages combined at both constant and fluc-

Table 2. Rate of development of immature stages of $S$. vagans at constant and fluctuating temperatures (proportion/day).

\begin{tabular}{|c|c|c|c|c|c|c|}
\hline \multirow{2}{*}{ Stages } & \multicolumn{5}{|c|}{ Constant temperature } & \multirow{2}{*}{$\begin{array}{c}\begin{array}{c}\text { Fluctuating } \\
\text { temperature }\end{array} \\
21.4^{\circ} \mathrm{C}\left(12.7-32.1^{\circ} \mathrm{C}\right)\end{array}$} \\
\hline & $12^{\circ} \mathrm{C}$ & $15^{\circ} \mathrm{C}$ & $20^{\circ} \mathrm{C}$ & $25^{\circ} \mathrm{C}$ & $30{ }^{\circ} \mathrm{C}$ & \\
\hline Egg & 0.061 & 0.100 & 0.193 & 0.260 & 0.459 & 0.246 \\
\hline 1st instar & 0.129 & 0.298 & 0.463 & 0.752 & 1.031 & 0.600 \\
\hline 2nd instar & 0.132 & 0.303 & 0.474 & 0.709 & 1.041 & 0.559 \\
\hline 3rd instar & 0.125 & 0.286 & 0.463 & 0.694 & 0.962 & 0.617 \\
\hline 4th instar & 0.110 & 0.277 & 0.459 & 0.610 & 0.806 & 0.578 \\
\hline Pupa & 0.062 & 0.105 & 0.226 & 0.293 & 0.360 & 0.215 \\
\hline All stages & 0.015 & 0.030 & 0.055 & 0.077 & 0.109 & 0.065 \\
\hline
\end{tabular}


Table 3. Regression of rate of development (1/y) with calculated values of correlation coefficient $(\mathrm{r})$, probability $(\mathrm{P})$, and minimum threshold temperature of development $(\mathrm{t})$ at constant temperatures. ${ }^{* *}: P<0.001$.

\begin{tabular}{lccc}
\hline Stages & Regression equations & $\mathrm{r}$ & $\mathrm{t}\left({ }^{\circ} \mathrm{C}\right)$ \\
\hline Egg & $\mathrm{Y}=-0.21223+0.02092 \mathrm{x}$ & $0.98^{* * *}$ & 10.14 \\
1st instar & $\mathrm{Y}=-0.46514+0.04898 \mathrm{x}$ & $0.99^{* * *}$ & 9.50 \\
2nd instar & $\mathrm{Y}=-0.46034+0.04855 \mathrm{x}$ & $0.98^{* * *}$ & 9.48 \\
3rd instar & $\mathrm{Y}=-0.4076+0.04478 \mathrm{x}$ & $0.99^{* * *}$ & 9.10 \\
4th instar & $\mathrm{Y}=-0.30784+0.03735 \mathrm{x}$ & $0.99^{* * *}$ & 8.24 \\
Pupa & $\mathrm{Y}=-0.13447+0.01689 \mathrm{x}$ & $0.98^{* * *}$ & 7.96 \\
All stages & $\mathrm{Y}=-0.04655+0.00509 \mathrm{x}$ & $0.99^{* * *}$ & 9.07 \\
\hline
\end{tabular}

tuating temperatures are shown in Table 1 . There were significant differences in all immature stages combined and for stage specific development times at different temperatures $(p<0.05)$ (Table 3$)$.

\section{Developmental rate}

The reciprocals of mean development time in days at both constant and fluctuating temperatures were calculated as a percentage of developmental rates per day (Table 2). The development rate for each stage and for all stages combined increased as the temperature increased. The development rate of the egg stage increased from $6.1 \%$ per day at $12{ }^{\circ} \mathrm{C}$ to $46 \%$ per day at $30{ }^{\circ} \mathrm{C}$. The daily rate recorded for all four larval instars combined was $18 \%$ per day at $12{ }^{\circ} \mathrm{C}$ and $96 \%$ per day at $30{ }^{\circ} \mathrm{C}$, and was $6.2 \%$ and $36 \%$ per day for the pupal stage at the same temperatures, respectively. The daily rate of development for eggs, larval and pupal stages was 24.6, 60.1, and 21.5\%, respectively, at fluctuating temperatures. The mean daily development was 0.06 and $0.36 \%$, at 12 and $30^{\circ} \mathrm{C}$ constant, and $0.21 \%$ at fluctuating temperatures $\left(12.7-32.1^{\circ} \mathrm{C}\right)$.

The relations between mean developmental rate and temperature were determined for each stage and for all immature stages combined (Table 3). Based on the linear regression equations the lower developmental threshold temperatures were estimated to be $10.1,9.5,9.5,9.1,8.2$, and $8.0^{\circ} \mathrm{C}$ for egg, 1 st, 2nd, 3rd, 4th instars, and pupal stages, respectively. The mean lower developmental threshold temperatures for all stages combined was $9.1^{\circ} \mathrm{C}$.

The parameters of the linear regression (intercept and slope) described the relationship between the developmental rate $(y)$ and temperature $(x)$ for each stage and for all stages combined in $S$. vagans. The correlation coefficient (r) for each stage and all stages combined was very high (from 0.98 to 0.99 ) indicating a good fit of data to the linear degree-days model within the tem- 
Table 4. Degree-days (DD) needed for development of immature stages of S. vagans at constant and fluctuating temperatures.

\begin{tabular}{|c|c|c|c|c|c|c|}
\hline \multirow{2}{*}{ Stages } & \multicolumn{5}{|c|}{ Constant temperature } & \multirow{2}{*}{$\begin{array}{c}\begin{array}{c}\text { Fluctuating } \\
\text { temperature }\end{array} \\
21.4^{\circ} \mathrm{C} \\
\left(12.7-32.1^{\circ} \mathrm{C}\right)\end{array}$} \\
\hline & $12^{\circ} \mathrm{C}$ & $15^{\circ} \mathrm{C}$ & $20^{\circ} \mathrm{C}$ & $25^{\circ} \mathrm{C}$ & $30^{\circ} \mathrm{C}$ & \\
\hline Egg & 47.91 & 58.47 & 56.35 & 61.06 & 45.56 & 49.94 \\
\hline 1st instar larva & 22.53 & 19.82 & 23.54 & 21.15 & 20.27 & 20.17 \\
\hline 2nd instar larva & 21.92 & 19.47 & 23.00 & 22.42 & 20.06 & 20.54 \\
\hline 3rd instar larva & 23.20 & 20.65 & 23.54 & 22.90 & 21.74 & 19.93 \\
\hline 4th instar larva & 26.48 & 21.30 & 23.76 & 26.08 & 25.92 & 21.28 \\
\hline Pupa & 47.15 & 56.05 & 48.18 & 54.22 & 58.10 & 57.20 \\
\hline All stage & 189.94 & 195.76 & 198.38 & 207.81 & 191.65 & 189.05 \\
\hline
\end{tabular}

perature range of 12 to $30{ }^{\circ} \mathrm{C}$ (Table 3). There were no significant differences among immature stages at lower development temperature threshold as their 95\% confidence intervals overlapped broadly. Therefore, the lower threshold temperature for all stages combined was used to determine the number of degree-days required to complete development for each stage and for all immature stages combined.

Degree Day $(D D)$

Degree-days (DD) requirements of $S$. vagans were calculated for each stage and for all immature stages combined from the developmental data and mean threshold developmental temperature $9.1^{\circ} \mathrm{C}$. Total mean DD estimated for development from egg to adult emergence and individual DD computed for egg, larval instars and pupal stages for constant and fluctuating temperature are presented in Table 4. DD calculated for the four larval instars ranged from 19.5 to 26.5 per instar over the range of constant and fluctuating temperatures, while for the pupal stage it varied from 47.2 to $58.1 \mathrm{DD}$ at the same temperatures.

\section{DISCUSSION}

This study is the first to investigate the effect of constant and fluctuating temperatures on the development of $S$. vagans. Information on developmental time, rate and thermal characteristics of this potential predator was gathered during this research. These data on S. vagans will be important for the development of forecast models to understand temperature ranges which affect 
development and survival of this potential predator and its synchronization with its host.

Effect of temperature on the development of S. vagans

In this study, development occurred at all temperatures except at very low $\left(10^{\circ} \mathrm{C}\right)$ or high temperatures $\left(35\right.$ and $\left.40^{\circ} \mathrm{C}\right)$. Therefore these extreme temperatures were outside the temperature range $\left(12-32^{\circ} \mathrm{C}\right)$ required for the development of $S$. vagans. Development did not appear at the aforementioned low temperature, but the eggs remained viable and hatched within a normal timeframe when exposed to $\geq 15^{\circ} \mathrm{C}$. Similarly, at higher temperature $\left(35^{\circ} \mathrm{C}\right)$ embryos developed within the egg, but died before or just after hatching. Our laboratory finding is supported by the results recorded for ambient temperatures for presence of this predator in the field. Our results are also partially in conformity with Putman (1955) and Roy et al. (2002), who reported that $S$. punctillum eggs did not hatch at 12 and $36^{\circ} \mathrm{C}$.

Developmental time decreased linearly with increased temperatures within the range $12-32{ }^{\circ} \mathrm{C}$ for all immature stages (including eggs) of $S$. vagans. For instance, it took 65.2 days at $12{ }^{\circ} \mathrm{C}$ and 9.2 days at $30^{\circ} \mathrm{C}$ constant, which was a little more than those reported by Richardson (1977) for S. loxtoni (52.3 and 8.3 days) at constant temperatures of 15 and $30^{\circ} \mathrm{C}$, respectively. This slight difference in development rates between these two Australian species may be due to the fact that $S$. vagans commonly occurs in coastal and subcoastal climates, while $S$. loxtoni is more common in the inland and Mediterranean climate areas (Britton \& Lee 1972, Readshaw 1975). On the other hand the total developmental time for S. vagans is shorter than for S. punctillum (68.5 and 12 days at 14 and $34^{\circ} \mathrm{C}$, respectively) as indicated by Roy et al. (2005) and S. gilvifrons (56.47 and 9.27 at 15 and $35{ }^{\circ} \mathrm{C}$, respectively) (TAghizadeh et al. 2008). In our study the total development time of $S$. vagans fed on T. urticae at $25^{\circ} \mathrm{C}$ was 13.1 days, compared with 15.3 days for $S$. loi at $23.8^{\circ} \mathrm{C}$ when fed on T. knzawai (Sнrн et al. 1991), 17 days for S. punctillum at $24^{\circ} \mathrm{C}$ fed on T. mcdanieli, and 18.5 days for S. gilvifrons at $25^{\circ} \mathrm{C}$ on T. urticae. The reason may be that $S$. vagans is smaller and adapted to different climatic zones than the above species; the other possible reason is that majority of them have different primary hosts.

Developmental time for individual immature stages of our study insect was also generally shorter than other species of the same genus. Mean development time for $S$. vagans eggs ( 9.9 days at $15^{\circ} \mathrm{C}$ and 2.2 days at $30^{\circ} \mathrm{C}$ ) was different than that reported by Richardson (1977) for S. loxtoni (14.3 days at $15^{\circ} \mathrm{C}$ and 1.9 days at $30^{\circ} \mathrm{C}$ ), and for for S. gilvifrons (13.0 days at $30^{\circ} \mathrm{C}$ ) (TAGHIZADEH et al. 2008). Larval stages of the most of the aforementioned Stethorus 
species also took longer to complete. While these differences might reflect different species characteristics, one of the other possible reasons that we studied the development of $S$. vagans in small Petri dishes, which has a larger area than Munger cells in which the other species that were studied. Another possible reason is that some of the other species of Stethorus were fed on a different species of prey mites.

The overall lower developmental threshold for all immature stages combined was estimated to be $9.07^{\circ} \mathrm{C}$ for $S$. vagans. Peterson et al. (1994) reported a threshold temperature of $10.5{ }^{\circ} \mathrm{C}$ for S. bifidus, and Roy et al. (2005) for S. punctillum and TAGHIZADEH et al. (2008) for S. gilvifrons demonstrated similar lower threshold temperatures. The differences among these results may be due to different species studied from different parts of the world and their different hosts. However, the overall consistency of the data confirms that temperature has significant effects on the development of Stethorus species.

The lower developmental threshold temperature for individual immature stages of $S$. vagans was $10.1,9.5,9.5,9.1,8.2,8.0$, and $9.1^{\circ} \mathrm{C}$ for egg, 1 st, 2nd, 3rd, 4th larval instars, pupa and all stages combined, respectively. The threshold temperature for the egg stage was higher than the rest of immature stages of $S$. vagans. This may have been possibly due to leaf structure and humidity in the cell, because the eggs were kept with the portion of leaf on which they were laid, while other immature stages were reared directly on dry filter paper. However, differences in threshold temperatures for different immature stages are not uncommon in insect species. For example, RichaRDSON (1977) recorded different lower threshold temperatures for different immature stages of $S$. loxtoni, with the highest $\left(11.5^{\circ} \mathrm{C}\right)$ being for the egg stage and lowest (6.5 and $6.0^{\circ} \mathrm{C}$, respectively) for 2 nd and 3rd instars. Our results also agreed with the observations recorded for $S$. bifidus, which has lower threshold temperatures of $11.9^{\circ} \mathrm{C}$ for the egg stage and $9.4^{\circ} \mathrm{C}$ for $3 \mathrm{rd}$ instar larvae (Peterson et. al. 1994). A similar difference in lower threshold temperatures within various stages was reported for S. gilvifrons with $14.11^{\circ} \mathrm{C}$ for egg stage, while the lowest was $5.20^{\circ} \mathrm{C}$ for 1 st instar larvae (TAGHIZADEH et al. 2008). Savopoulou-Sultani (1997) also reported different threshold temperatures from 8.2 to $15.4{ }^{\circ} \mathrm{C}$ for different immature stages of euonymus scale, Euonymus japonica and Nordin and O'CANNA (1985) recorded different lower thresholds for stages of the fall webworm, Hyphantria cunea at 14, 11, and 12 ${ }^{\circ} \mathrm{C}$ for egg, larva, and pupal stages, respectively.

The lower developmental threshold temperature we recorded for for the egg stage appears to be valid, based on the data showing that eggs did not develop at $10^{\circ} \mathrm{C}$, although they remained viable for a long time (60 days), and subsequently hatched in the normal time period when exposed to temperatures of $\geq 15^{\circ} \mathrm{C}$. This characteristic may enable this species to survive winter 
in the egg stage and hatch when temperature becomes favorable. However, in the field very few eggs appear to hatch in winter even when the temperature rises above from $10{ }^{\circ} \mathrm{C}$, because field counts during a two year period indicated that the number of motile $S$. vagans declined under these conditions (KHAN 2001).

VAN DE VRIE et al. (1972) calculated a lower threshold temperature of 10 ${ }^{\circ} \mathrm{C}$ for T. urticae, while Readshaw (1975) reported a lower threshold of around 9 to $10{ }^{\circ} \mathrm{C}$ for eggs and immature stages of this mite species. Therefore the lower threshold temperatures of prey and predator are in harmony. The developmental period we recorded for $S$. vagans from egg to egg was 43.8, 23.6 and 10.3 days at 15,20 and $30^{\circ} \mathrm{C}$, respectively, and was longer than T. urticae developmental period, which was 36.4, 16.6 and 7.3 days at the aforementioned temperatures (Khan 2001, Bower \& Thwaite 1995). The oviposition rate recorded for T. urticae was also higher i.e. 200 eggs at a rate of 3-14 eggs / female /day in their life span of 3-4 weeks (Bower \& Thwaite 1995). However the rate of predation of by $S$. vagans larvae and adults was much higher than the rate of T. urticae oviposition and development (i.e. larval instars 27.9-152 eggs/day, adult males and ovipositing females 63.5-142.7 eggs/day) (Bower \& Thwaite 1995, Khan 2001).

Eggs of $S$. vagans developed into larvae at a constant temperature of $35^{\circ} \mathrm{C}$, but they could not survive for a long time. The temperature during summers in the Hawkesbury valley, New South Wales, Australia does not rise often above $35^{\circ} \mathrm{C}$. On the other hand temperatures in the microclimate within trees, plants and shrubs are lower than the normal ambient temperature, which is likely to provide a suitable environment for $S$. vagans stages to survive and reproduce.

\section{Degree Days (DD)}

The degree-days (DD) model is the most widely used approach for describing insect development rate and in predicting insect developmental times as a function of temperature. There were slight differences between the DD calculations for immature stages and all stages combined resulted from data generated at different constant and fluctuating temperatures. These slight differences may be due to temperature fluctuations occurring when they were removed from the designated temperature for observation, although this time was tried to be minimized. However, differences in DD within the life stages of insect species at constant and fluctuating temperatures have been reported by a number of authors. For example, Hanula et al. (1987) observed different DD for immature stages of pine cone worm, Dioryctria amatella, at different constant and fluctuating temperatures. Tolley and NeImczyк (1988) also re- 
ported a deal of variation in DD for the fruit fly, Oscinella frit, calculated from eight constant temperatures. Our results (207.8 DD) observed at a constant $25^{\circ} \mathrm{C}$ for all stages combined of $S$. vagans are quite close to that recorded for all stages combined of S. bifidus (217 DD) and S. gilvifrons (222.72 DD) estimated at a constant $27.5^{\circ} \mathrm{C}$ and $28^{\circ} \mathrm{C}$, respectively (Peterson et al. 1994, Taghizadeh et al. 2008).

Threshold temperature and DD for the development of the predators can play a significant role in the selection of potential predators, which can be used in various ecological zones (Perdikis \& LyKouressis 2002). The lower threshold temperature and thermal constant have been estimated from simple linear models for a number of insect pests and their natural enemies (Ror et al. 2005).

In conclusion, this study describes the temperature-dependent development relationship of an Australian population of $S$. vagans at a range of constant and fluctuating temperature commonly occurs in coastal and subcoastal climates. This study can be helpful in predicting $S$. vagans population development in the field. Information from this study can be used for its mass rearing, predation studies, thermal adaptation, and optimizing synchronization of the predator and its host. Furthermore, this information can be incorporated in IPM programs for the management of T. urticae in field and green house crops.

\section{REFERENCES}

Andrewartha, H. C. \& Birch, L. C. (1954): The distribution and abundance of animals. University of Chicago Press, Chicago, $782 \mathrm{pp}$.

Bower, C. C. \& Thwaite, W. G. (1995): The mite management manual. A practical guide to integrated mite control. Agriculture Research of Veterinary Centre, Orange NSW Agriculture, Australia, 45 pp.

Britton, E. B. \& Lee, B. (1972): Stethorus loxtoni sp. n (Coleoptera: Coccinellidae) a newly discovered predator of the two-spotted mite. Journal of the Australian Entomological Society 11: 55-60. https://doi.org/10.1111/j.1440-6055.1972.tb01604.x

Costello, R. A., Elliot, D. P. \& Gillespie, D. R. (1992): Integrated control of greenhouse pests. Ministry of Agriculture, Fisheries and Food, British Colombia, 19 pp.

DeloACh, C. L. (1974): Rate of increase of populations of cabbage, green peach and turnip aphids at constant temperature. Annals of Entomology Society of America 67: 332-340. https://doi.org/10.1093/aesa/67.3.332

Elliott, N. C., Kickhefer, R. W. \& Walgenbach, D. D. (1988): Effect of constant and fluctuating temperatures on developmental rates and demographic statistics for the cornleaf aphid (Homoptera: Aphididae). Journal of Economic Entomology 81(5):1383-1389. https://doi.org/10.1093/jee/81.5.1383

Fan, F., Groden, E. \& Drummond, F. A. (1992): Temperature dependent development of Mexican bean beetle (Coleoptera: Coccinellidae) under constant and variable tem- 
peratures. Journal of Economic Entomology 85(5): 1762-1770. https://doi.org/10.1093/ jee/85.5.1762

Gordon, R. D. \& Anderson, D. M. (1979): The genus Stethorus Weise (Coleoptera: Coccinellidae). The Coleopterists Bulletin 33(1): 61-67.

Gough, N. (1992) Prospects for IPM in greenhouse ornamentals in Australia. Entomology Branch, Department of Primary Industry Queensland, $21 \mathrm{pp}$.

HAN, S. H., JunG, C. \& LeE, J. H. (2003): Release strategies of population dynamic of Amblyseius womersleyi and Tetranychus urticae: Release position in pear. Journal of AsiaPacific Entomology 6: 221-227. https://doi.org/10.1093/jee/85.5.1762

Hanula, J. L., Debarr, G. L. \& Berisford, C. W. (1987): Threshold temperature and degreedays estimates for development of immature southern pine corn worm (Lepidoptera: Pyralidae) at constant and fluctuating temperatures. Journal of Economic Entomology 80: 62-64. https://doi.org/10.1093/jee/80.1.62

Hayakawa, D. L., Grafius, E. \& Stehr, F. W. (1990): Effects of temperature on longevity, reproduction, and development of the asparagus aphid (Homoptera: Aphididae) and the parasitoid, Diaeretiella rapae (Hymenoptera: Braconidae). Environmental Entomology 19: 890-897. https://doi.org/10.1093/ee/19.4.890

Helle, W. \& SABelis, M. W. (1985): Spider mites: their biology, natural enemies and control. Vol. 1B.211-245. Elsevier Science Publishers, Amsterdam, The Netherlands, 458 pp.

Honek, A. \& Kocourek, F. (1990): Temperature and development time in insects: A general relationship between thermal constants. Zoologisches Jahrbuch, Abteilung für Systematik 117: 401-439.

Houston, K. J. (1980): A revision of the Australian species of Stethorus Weise (Coleoptera: Coccinellidae). Journal of The Australian Entomology Society 19(2): 81-91. https://doi. org/10.1111/j.1440-6055.1980.tb00968.x

Huffaker, C. B., Berryman, A. \& Turchin, P. (1999): Dynamics and regulation of insect populations. Pp. 269-305. In: Huffaker, C. B. \& Gutierrez, A. P. (eds): Ecological entomology. 2nd ed., Wiley, New York.

Hull, L. A. (1977): The functional and numerical responses of Stethorus punctum (Coleoptera: Coccinellidae) to densities of the Panonychus ulmi (Acarina: Tetranychidae). Ph.D. Dissertation, Pennsylvania State University, USA.

Hutchison, F. (1992): What pest is that? Bay Books Harper Collins, Sydney, Australia, 93 pp.

Jeppson, L. R., KeIfer, H. H. \& BAKer, E. W. (1975): Mite injurious to economic plants. University of California Press, Berkeley, $614 \mathrm{pp}$.

JunG, C. (2005): Some evidence of aerial dispersal of two-spotted spider mite from an apple orchard into soybean field. Asia Pacific Entomology 8: 279-283. https://doi.org/10.1016/ S1226-8615(08)60246-0

KheradpiR, N., Khalghani, J., Ostovan, H. \& Rezapanah, M. R. (2007): The comparison of demographic traits in Tetranychus urticae Koch (Acari: Tetranychidae) on five different greenhouse cucumber hybrid (Cucumis sativus). Acta Horticulturae 47: 425-430. https://doi.org/10.17660/ActaHortic.2007.747.53

KHAN, I. (2001): Aspects of the biology of the ladybird beetle Stethorus vagans (Blackburn) (Coleoptera: Coccinellidae). PhD Dissertation, The University of Western Sydney, New South Wales, Australia, 183 pp.

McMaugh, J. (1998): What garden pest or disease is that? Life Time Distributors, Sydney, Australia, 206 pp.

Michels-Jr, G. J. \& Behle, R. W. (1991): Effect of two prey species on the development of Hippodamia sinuata (Coleoptera: Coccinellidae) larvae at two constant temper- 
atures. Journal of Economic Entomology 84(5): 1480-1484. http://dx doi.org/10.1093/ jee/84.5.1480

Michels-JR, G. J. \& BeHLe, R. W. (1992): Evaluation of sampling methods for lady beetles (Coleoptera: Coccinellidae) in grain sorghum. Journal of Economic Entomology 85: 2251-2257. https://doi.org/10.1093/jee/84.5.1480

Nordin, G. L. \& O'CANNA, D. (1985): Developmental threshold temperatures and thermal constants for two types of fall worms, Hyphantria cunea (Drury) (Lepidoptera: Arctiidae) occurring in central Kentucky. Journal of Kansas Entomological Society 80(1): 62-64.

Pavlova, G. A. (1975): Stethorus - a predator of the spider mite. Zashchita Rastenii 1: 23-24.

Penrose, L. J., Thwaite, W. G. \& Slack, J. M. (1997): Avoiding resistance to pesticides. Orchard Plant Protection Guide. NSW Agriculture, pp. 25-26.

Perdikis, D. C. \& Lykouressis, D. P. (2002): Thermal requirements for development of the polyphagous predator Macrolophus pygmaeus (Hemiptera: Miridae). Environmental Entomology 31: 661-667. https://doi.org/10.1603/0046-225X-31.4.661

Petersons, G. P., MacGregor, G. P., Springlet, B. O. P. \& Poppy, A. D. J. (1994): Development of Stethorus bifidus in relation to temperature: implication for regulation of gorse spider mite populations. Proceedings of Forty-Seventh New Zealand Plant Protection Conference, New Zealand, 9-11 August 1994, pp. 103-106.

Price, P. W. (1975): Insect ecology. John Wiley and Sons Inc., New York, 868 pp.

Putman, W. L. (1955): Bionomics of Stethorus punctillum Weise (Coleoptera: Coccinellidae) in Ontario. Canadian Entomologist 87: 9-33. https://doi.org/10.4039/Ent87506-11

Readshaw, J. L. (1975): The ecology of tetranychid mites in Australian orchards. Journal of Applied Ecology 12(2): 473-495. https://doi.org/10.2307/2402169

Richardson, N. L. (1977): The biology of Stethorus loxtoni Britton and Lee (Coleoptera: Coccinellidae) and its potential as predator of Tetranychus urticae (Acarina: Tetranychidae) in California. Ph.D. Thesis, University of California, Berkeley, USA.

Rodriguez-Saona, C. \& Miller, J. C. (1999): Temperature dependent effects on development, mortality, and growth of Hippodamia convergens (Coleoptera: Coccinellidae). Environmental Entomology 28: 518-522. https://doi.org/10.1093/ee/28.3.518

Roy, M., Brodeur, J. \& Cloutier, C. (2000): Relationship between temperature and development rate Stethorus punctillum (Coleoptera: Coccinellidae) and its prey Tetranychus mcdanieli (Acari: Tetranychidae). Environmental Entomology 31: 177-187. https://doi.org/10.1603/0046-225X-31.1.177

Roy, M., Brodeur, J. \& Cloutier, C. (2005): Seasonal activity of the spider mite predator Stethorus punctillum (Coleoptera: Coccinellidae) and Neoseiulus fallacies (Acarina: Phytoseiidae) in raspberry, two predators of Tetranychus mcdanieli (Acarina: Tetranychidae). Biological Control 34: 47-57. https://doi.org/10.1016/j.biocontrol.2005.03.012

Sanderson, J. P., Barnes, M. M. \& Youngman, M. M. (1989): Developmental rate of navel orange-worm (Lepidoptera: Pyralidae) at various constant temperatures. Journal of Economic Entomology 82(4): 1096-1100. https://doi.org/10.1093/jee/82.4.1096

Savopoulou-Sultani, M. (1997): Laboratory rearing of Euonymus scale (Homoptera: Diaspididae) at different temperatures. Journal of Economic Entomology 90(4): 955-960. https://doi.org/10.1093/jee/90.4.955

Shin, C. I. T., Lin, P. J. \& ChAng, T. W. (1991): Biology, predation, life table and intrinsic rate of increase of Stethorus loi Sasaji. Plant Protection Bulletin 33(3): 290-300.

Singh, J. \& RAY, R. (1977): Stethorus sp. (Coleoptera: Coccinellidae), a predator of Tetranychus neocaledonicus Andre on okra at Varanasi. Acarology Newsletter 4: 5-6. 
Sokal, R. R. \& Rohlf, F. J. (1995): Biometry. H. Freeman and Company, New York, 887 pp. Thwaite, G. (1993): Pome fruit entomology review. Report of a meeting held at Agricultural Research and Veterinary Centre Orange, NSW, Australia.

Taghizadeh, R., Fathipour, Y. \& Kamali, K. (2008): Temperature-dependent development of acarophagous ladybird Stethorus gilvifrons (Mulsant) (Coleoptera: Coccinellidae. Journal of Asia Pacific Entomology 11: 145-148. https://doi.org/10.1016/j.aspen.2008.07.001

Tolley, M. P. \& NeimczyK, H. D. (1988): Upper and lower threshold temperatures and degree-day estimates for development of fruit fly (Diptera: Chloropidae) at constant temperatures. Journal of Economic Entomology 81(5): 1346-1351. https://doi. org/10.1093/jee/81.5.1346

Van deVrie, M., McMurtry, J. A. \& Huffaker, C. B. (1972): The ecology of tetranychid mites and their natural enemies: review III. Biology, ecology and pest status and host-plant relations of tetranychids. Hilgardia 41: 343-432. https://doi.org/10.3733/ hilg.v41n13p343

Woodson, W. D. \& Edelson, J. V. (1988): Developmental rate as a function of temperature in a carrot weevil, Listronotus texanus (Coleoptera: Curculionidae). Annals of Entomology Society of America 81: 252-254. https://doi.org/10.1093/aesa/81.2.252

Received May 20, 2015, accepted October 24, 2015, published March 3, 2017 